\title{
Staphylococcus capitis
}

National Cancer Institute

\section{Source}

National Cancer Institute. Staphylococcus capitis. NCI Thesaurus. Code C86752.

A species of facultatively anaerobic, Gram positive, cocci shaped bacteria in the phylum

Firmicutes. This species is catalase positive, and negative for alkaline phosphatase,

urease, oxidase and coagulase. It is able to ferment glucose, fructose, lactose, trehalose, glycerol, and mannitol, but not arabinose, sucrose, xylose, turanose, xylitol, rhamnose, or maltose. S. capitis is part of the human skin flora but is a pathogen that can cause pneumonia, urinary tract infection, catheter related bacteremia, cellulitis, and endocarditis. 